\title{
Correlation Between Students' Motivation and English Achievement at Secondary School Level
}

\author{
Rosmawati Mastur ${ }^{1, *}$ Rofiqoh $^{2}$ Aminah Suriaman ${ }^{3}$ \\ 1,2,3 Tadulako University. Palu. Central Sulawesi. Indonesia \\ ${ }^{*}$ Corresponding author. Email: rosmawati_jalil@yahoo.com
}

\begin{abstract}
The study is aimed at investigating the correlation between students' motivation and English achievement at secondary school level. This research was conducted at SMPN 1 Banawa Tengah. The population of the research was all ninth grade students of SMPN 1 Banawa Tengah. The total number of the population was 111 students. Data were collected through questionnaire developed by Gardner; Attitude / Motivation Test Battery: International AMTB Research Project (English version). The English achievement was obtained from the students' average scores coming from the first semester of the seventh grade up to the sixth semester of the ninth grade. The technique which was used to analyze the data was Pearson Product - Moment Correlation which was computed by the Statistical Package for Social Science (SPSS) 25 for windows. The result of the analysis showed the level of significance that was $0.000<0.05$ with coefficient correlation 0.680. The result shows that there is a significant correlation between motivation and English achievement. It means that the more motivation students have in studying, the higher achievement score will be.
\end{abstract}

Keywords: Correlation, Students' Motivation, English Achievement, Secondary School Level

\section{INTRODUCTION}

Academic achievement becomes one of the important things in teaching and learning process. This is in accordance with Bhat (2013) states that academic achievement possesses a very imperative place in education as well as in the learning process. Therefore, it can be stated that academic achievement represents outcomes performance that indicates the extent of people having accomplished specific goals that are focused on activities in instructional environments such as at school, college, or university. It can be stated that when students can master and communicate the language learned both in written and orally it indicates that they are success in their academic achievement. If it is related to the English subject, the academic achievement refers to the mastery of both the language skills and language components. Therefore, it is very urgent for students to master both in order to get success in academic achievement.

Successfulness in academic achievement is strongly linked to the positive outcomes (Scholarship, 2011). When the students have been successful in their academic achievement, it can describe to what extent they have been successful to master the materials given by their teacher. Also, by having successfulness in academic achievement can help the teacher to know whether or not the learning method applied has been appropriate. However, to get successfulness in academic achievement is not easy. There are several factors contributing it. One of them is motivation.

Motivation is one of the most important factors that will influence students' English achievements or performance (Kurt and Kecik, 2017). It means that motivation has significant role in supporting the successfulness of English achievement. In other words, learning motivation can affect the students' way of learning. In this case, when students have high motivation, they will try to do various ways of learning to obtain good achievement. Many researchers have conducted many studies about the relationship between motivation and academic achievement in English. Some of them are Sharma Deepika and Sharma Susha (2018); they found that there were significant correlations between self-concept, motivation and academic achievement of late childhood school students. Another research from Kpolovie, Joe, and Okoto (2014); they found that there was a significant correlation between 
students' interest in learning and attitude to school individually and collectively on their academic achievement. Moreover, another research from Gbollie and Keamu (2017); they found that there was significant relationship between motivational beliefs and learning strategy used by Liberian Junior and Senior High School to academic performance.

It is a natural thing if motivation becomes one of the basic elements for human beings in achieving something, especially if it is related to teaching and learning process in English, learning motivation becomes one of the main important factors in determining the successfulness of developing English both as a second language and as a foreign language. In this case, motivation plays a vital role in English teaching, not only aptitude, but also intelligence (Zhang, 2015). It means that, it is very necessary to build up motivation so that it will make easier the learning process such as transferring knowledge or information between teacher and student. In addition, motivation is not only an intensive desire for learning and acquiring knowledge of English. It also becomes an inner cause that encourages the students to keep going up in learning English with enthusiasm and willingness. In other words, learning motivation becomes one of the important factors in teaching and learning process because it can drive students from boredom to be interested in learning English. Furthermore, it cannot be denied that motivation becomes one of the fundamental factors for academic success. It is because of internal and external factors that stimulate desire and energy in people to be continually interested and committed to job, role, or subject, or to make an effort to attain a goal (Gbollie and Keamu, 2017). It means that by having high motivation, someone can have desire to do and even to reach something, especially if it is related to the successfulness of academic achievement in English subject for students. The motivation itself is very necessary for all of the students in order to help them to get success in mastering knowledge in English well both in written and orally.

Based on the reasons above, the research tries to investigate the correlation between students' motivation and English achievement at secondary school level. This research is slightly different from the researches before, in which most of the students at the researcher' place conducted the research began to know and to understand English subject when they were in the seventh grade of Junior High School and most of the parents of students at this place have low economic income such as fishermen, labor, and housekeeper, in which Chandra and Azimuddin (2013) state that Socio Economic status is the most important variable in determining the academic achievement. Therefore, the researcher wanted to investigate whether there is or not significant correlation between students' motivation and English achievement at secondary school level as the title of her research.

\section{OVERVIEW}

Correlational research is one of the research designs that are applied by the researcher to know the relationship between two variables or more. According to Fraenkel (2012), correlation research is also called associational research, like the relationship among two or more variables studied without any attempt to influence them. In this type of research, researcher tries to connect a variable with other variables to understand a phenomenon by determining the level or degree of relationship between these variables. The level of the relationship is indicated by the value of the correlation coefficient which serves as a tool to compare the variability of measurement results against these variables. Knowledge about the level of the relationship is expected to increase understanding of factors in the complex characteristics of a phenomenon such as learning achievement.

Furthermore, the correlation coefficient is a measure of correlation strength can range from -1.00 to 1.00 . There are three possible result of a correlation study, those are; a positive correlation, a negative correlation, and no correlation. Perfect positive correlation would result in as score of 1 . Perfect negative correlation would result in -1 (Nunan, 1992).

Furthermore, in order to know the level of correlation between the two variables, the following is the interpretation of correlation coefficients to find the relationship; it can be guided by the provisions listed in the following table:

\begin{tabular}{lll}
\hline $\begin{array}{l}\text { Size of } \\
\text { Correlation }\end{array}$ & the & $\begin{array}{l}\text { Coefficient } \\
\text { Interpretation }\end{array}$ \\
\hline 0.8 to 1.0 & Very strong relationship \\
0.6 to 0.8 & Strong relationship \\
0.4 to 0.6 & Moderate relationship \\
0.2 to 0.4 & Weak relationship \\
0.0 to 0.2 & Weak or no relationship \\
\hline
\end{tabular}

Adopted from Salkind (2017)

In general motivation is the reason for people's actions, desires, and needs. Motivation is also one's direction to behavior. Ningrum and Matondang (2017) state that motivation is the driving force by which humans achieve their goals. Moreover, Gilakjani, Leong, and Sabouri (2012) state that motivation energizes human being and provides direction. Moreover, Fontecha and Alonso (2014) state that motivation is considered one of the pillars of Content and Language Integrated Learning (CLIL) implementation. From those definitions, it can be concluded that motivation cannot be neglected especially in language teaching process and it becomes 
very important, because it can help being successful in English learning. In other words, by having good motivation in learning English, it can make students more enjoy and happier to learn English. Furthermore, Ryan and Deci (2000) divide motivation into two types, they are:

\subsection{Intrinsic Motivation}

Intrinsic motivation is a motivation to do an activity because of itself. Harmer (2001) states that intrinsic motivation comes from within the individual. In this case, someone who is motivated in intrinsically does, practices, or works some activities because he/she enjoys them. For example, another student may study hard for a test because he or she enjoys the content of the course (Santrock, 2008). Therefore, it can be concluded that when someone feel happy or enjoy doing something it means that he or she is motivated intrinsically. In addition, Gage and Berliner (1984) say that intrinsic motivation can be found in students' interest, need, hobby and goal in learning. It is because they come from the students themselves naturally and it is not forced or influenced by something or someone else. In other words, intrinsic motivation refers to an individual's personal interest, satisfaction, and enjoyment. The factors affecting it are internal, therefore, a student learns without expecting anything such as grades or praise in return.

\subsection{Extrinsic Motivation}

Extrinsic motivation is a motivation to do a work or an activity as a means of way to achieve a target. Ur (1996) states extrinsic motivation derives from the influence of some kind of external incentive, as distinct from the wish to learn for its own sake or interest in task. In this case, someone who is motivated in extrinsically does and performs something, because she/he thinks that her/his contribution will get a good result. Moreover, Gage et al. (1984) state motivation appears or comes from teacher, parents, and environment. They can support students' learning motivation externally by transferring the knowledge (from the teachers to students); by influencing students' attitude to learn (people who close to them like parents); and providing good environment to learn.

\subsection{Academic Achievement}

Academic achievement means the result what the students have learned that is usually measured by giving the test. It becomes one of the important parts in the process of teaching and learning is that the result of students' academic achievement. It is because to see and measure students' ability in understanding the subject taught. Also, it is to know about what students have learned in relation to their knowledge and their skill that they have obtained and learned. Henceforward, it can be seen by the result of the students' academic achievement through school final exam test.
After finishing the teaching and learning process, it is expected to know how far the students master the given material and achieve the instructional objectives. It is also in English teaching and learning process. Test or evaluations are needed to measure how far the students master the material. In general, students will try to achieve success in learning English. According to Hornby (2003), achievement is something done successfully, with effort and skill. While Brown (2004) says that achievement test is related directly to classroom lessons, units, or even a total curriculum. From the definitions above, the researcher can conclude the definition of achievement is students' effort and skill in a subject area as a result of specific instruction or outcomes of learning. The result that student has reached in the learning and teaching process in a certain period and it is reflected in symbol, number, letter, or sentence. Talking about the result of students' academic achievement in EFL learning is also very important, because it becomes a benchmark for the English teachers to know whether the material taught has been mastered by the students or not. Also, it is to give feedback for the English teachers to improve their teaching and to provide the teachers with the information to revise the class or program.

There are many ideas about dividing of achievement. One of the come from Bloom (In Arifin, 2012) says that achievement of the study divided into three domains. First domain is cognitive, the second is affective, third is psycho motoric. Each domain is created from simple to difficult and from reality to abstract. They are:

\subsubsection{Cognitive Domain}

The cognitive domain involves the development of our mental skills and the acquisition of knowledge. For example: a child recites the English alphabet.

\subsubsection{Affective Domain}

The affective domain includes factors such as student motivation, attitudes, perceptions and values. For example: teachers can increase their effectiveness by considering the affective domain in planning courses, delivering lectures and activities, and assessing student learning.

\subsubsection{Psycho motoric Domain}

The Psycho motoric domain is ability of the students relate to the moving hierarchy, from the simplest movement to the complex movement. In behavioral examples include driving a car and eye-hand coordination tasks such as sewing, throwing a ball, typing, operating a lathe, and playing a trombone.

Talking about academic achievement is not only talking about the ability of the students to get success in obtaining what they have learned but also it cannot be separated from the role of family background. There are many researchers stated the importance of family in supporting the academic achievement of a child. The 
first is Majoribanks (1996) states that families with high socio economic status often have more success in preparing their young children for school because they have access to a wide range of resources to promote and support young children's development. The second is Adams (1996) states that the low socio economic status has negative effect on the academic performance of students because the basic needs of students remain unfulfilled and hence they do not perform better academically. The third is US Department of Education (2003) states that the low socio economic status causes environmental deficiencies which results in low selfesteem of students. The fourth is Krashen (2005) states that students whose parents are educated score higher on standardized test than those whose parents were not educated. So, from all the statements above, it can be concluded that family background in particular socio economic status of the family have contribution to influence the academic of the students.in this case the higher socio economic status or the higher parents' education, the higher learning achievement of their children.

\subsection{Correlation between Learning Motivation and English Learning Achievement of the Students}

Students' academic achievement becomes one of the important things in teaching learning process, especially in English, because it can be the parameter of the students' learning process and also as a subject self-evaluation. Moreover, it can help the teachers to know students' mastery toward materials taught, so that the teachers can decide whether they need to do remedial or not. Therefore, in order to make students' academic achievement increase, learning motivation in English from the students is much needed.

There are many opinions from the researchers about learning motivation. One of them comes from Kitjaroonchai (2012). He states that motivation means the strong desire to learn and the satisfaction experienced in the learning process and the learning outcomes. So, it can be concluded that in general, the students having good motivation in learning English certainly their academic achievement in English can increase and be better as the result of teaching learning process.

Moreover, Harmer (2001) states that the motivation which students bring to class is bigger single factor affecting their success, its energy of students which come from inside or outside encouraging them to do something. It means that students with learning motivation will get push from inside and outside to learn, to think and to search new materials for their English lesson. They will try to get the best learning outcomes. Based on those explanations, the researcher assumed that students' motivation may give big influence toward their English achievement. Therefore, the researcher wanted to investigate whether there is or not significant correlation between students' motivation and English achievement at secondary school level as the title of her research.

\section{METHOD}

This research applied correlational study in a quantitative design. In this case, it used correlational statistical analysis to describe and measure between two variables in this research. In other words, it was applied to analyze whether there is or not significant correlation between students' motivation and English achievement at secondary school level. The reason of choosing the method is the research wants to know the strength of the relation of two variables based on correlation coefficient.

In this research, the population was the ninth grade students of SMPN1 Banawa Tengah. The total of them are 111 students. The sample used a total sampling technique, so all of the population became the sample of the research.

The data in this research belongs to non-test. There were two instruments applied in this research. They consisted of Questionnaire and data related to students English achievement. The questionnaire was applied to collect the data of students' motivation. It consisted of forty statements; twenty statements for intrinsic motivation and twenty statements for extrinsic motivation. They were adopted from the questionnaire developed by Gardner (2004) Attitude / Motivation Test Battery: International AMTB Research Project (English version). It is rated by using Likert Scale that consisted of six classifications as follows:

\begin{tabular}{ll}
\hline Classification & Scale Value \\
\hline Strongly Agree & 6 \\
Moderately Agree & 5 \\
Slightly Agree & 4 \\
Slightly Disagree & 3 \\
Moderately Disagree & 2 \\
Strongly Disagree & 1 \\
\hline
\end{tabular}

Adopted from Gardner (2004)

Furthermore, to interpret the students' motivational level, the researcher applied the guidance designed by Azwar (2012) as follows:

\begin{tabular}{ll}
\hline Low & $\mathrm{X}<\mathrm{M}-1 \mathrm{SD}$ \\
Moderate & $\mathrm{M}-1 \mathrm{SD}<\mathrm{X}<\mathrm{M}+1 \mathrm{SD}$ \\
High & $\mathrm{M}+1 \mathrm{SD}<\mathrm{X}$ \\
\hline
\end{tabular}

Adopted from Azwar (2012)

The second instrument was the data related to Students' English Achievement. It was applied to collect the data of students' English learning Achievement, in which it was taken from the students' average scores from the first semester up to sixth semester came from the rapport of the students of SMPN 1 Banawa Tengah. In this case, students' grades obtained from the first semester of the seventh grade up to sixth semester of the ninth grade. Furthermore, in 
order to interpret the level of students' English learning achievement, the researcher applied the guidance designed by Ministry of Education and Culture (2018) as follows:

\begin{tabular}{ll}
\hline Score Range & $\begin{array}{l}\text { Level of English Learning } \\
\text { Achievement }\end{array}$ \\
\hline $86-100$ & Very Good \\
$71-85$ & Good \\
$56-70$ & Enough \\
$\leq 55$ & Poor \\
\hline
\end{tabular}

Kementrian Pendidikan dan Kebudayaan (2018)

To test the hypothesis, this research used Pearson Product - Moment Correlation to investigate the relationship between 2 variables (bivariate analysis); between motivation and students' English achievement. Furthermore, in order to know the level of correlation between the two variables, the researcher provided the interpretation of correlation coefficients to investigate whether there is or not significant relationship between variables; students' motivation and English achievement, in which it can be guided by the provisions listed in the following table:

\begin{tabular}{|c|c|}
\hline $\begin{array}{l}\text { Size of } \\
\text { Correlation }\end{array}$ & $\begin{array}{l}\text { Coefficient } \\
\text { Interpretation }\end{array}$ \\
\hline 0.8 to 1.0 & Very strong relationship \\
\hline 0.6 to 0.8 & Strong relationship \\
\hline 0.4 to 0.6 & Moderate relationship \\
\hline 0.2 to 0.4 & Weak relationship \\
\hline 0.0 to 0.2 & Weak or no relationship \\
\hline
\end{tabular}

Adopted from Salkind (2017)

\section{RESEARCH FINDING}

As mention before, the data collection was carried out from the ninth grade students of SMPN 1 Banawa Tengah. There were 111 students who have completed the questionnaire. In this section, the researcher presents the findings focusing on correlation between students' motivation and English achievement. The data gained from the scores of intrinsic motivation above, it can be classified into three motivational levels as follow:

\section{INTRINSIC_CAT}

Valid

Frequenc Percen Percen Cumulativ

\begin{tabular}{|c|c|c|c|c|c|}
\hline & & $\mathrm{y}$ & $\mathrm{t}$ & $\mathrm{t}$ & e Percent \\
\hline \multirow{4}{*}{$\begin{array}{l}\text { Vali } \\
\text { d }\end{array}$} & LOW & 20 & 18.0 & 18.0 & 18.0 \\
\hline & $\begin{array}{l}\text { MODERAT } \\
\text { E }\end{array}$ & 73 & 65.8 & 65.8 & 83.8 \\
\hline & HIGH & 18 & 16.2 & 16.2 & 100.0 \\
\hline & Total & 111 & 100.0 & 100.0 & \\
\hline
\end{tabular}

From the data above, there are twenty students having low motivation in English learning and the percentage is $18.0 \%$. There are seventy three students having moderate motivation in English learning and the percentage is $65.8 \%$. The last, there are eighteen students having high motivation in English learning and the percentage is $16.2 \%$. Furthermore, the data gained from the score of extrinsic motivation above, it can be classified into three motivational levels as follow:

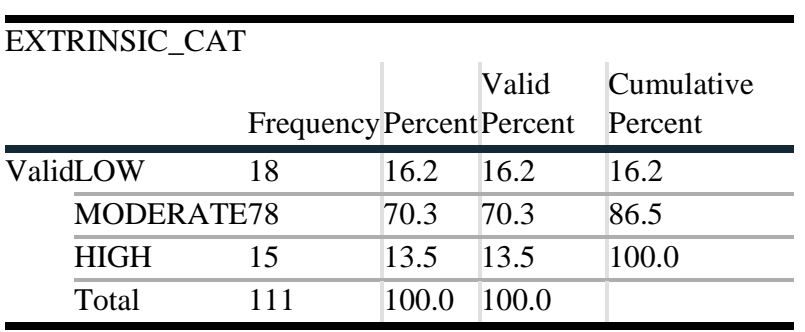

From the data above, there are eighteen students having low motivation in English learning and the percentage is $16.2 \%$. There are seventy eight students having moderate motivation in English learning and the percentage is $70.3 \%$. The last, there are fifteen students having high motivation in English learning and the percentage is $13.5 \%$. Furthermore, the data gained from the score of English learning achievement above, it can be classified into four learning achievement levels as follow:

\begin{tabular}{|c|c|c|c|c|}
\hline \multicolumn{5}{|c|}{ ACHIEVEMENT_CAT } \\
\hline & Frequency & Percen & $\begin{array}{l}\text { Valid } \\
\text { tPercent }\end{array}$ & $\begin{array}{l}\text { Cumulative } \\
\text { Percent }\end{array}$ \\
\hline ValidGOOD & 90 & 81.1 & 81.1 & 81.1 \\
\hline $\begin{array}{l}\text { VERY } \\
\text { GOOD }\end{array}$ & 21 & 18.9 & 18.9 & 100.0 \\
\hline Total & 111 & 100.0 & 100.0 & \\
\hline
\end{tabular}

Based on the table above, there are ninety students having good in English achievement and the percentage is $81.1 \%$ and there are twenty one students having very good in English learning achievement and the percentage is $18.9 \%$.

Linearity test is used to determine whether or not the relationship between variables in the form of a straight lines (linear relationship). Here the description of linearity testing:

\begin{tabular}{|c|c|c|c|c|c|c|c|}
\hline \multicolumn{8}{|c|}{ ANOVA Table } \\
\hline & & & $\begin{array}{l}\text { Sum of } \\
\text { Squares }\end{array}$ & & $\begin{array}{l}\text { Mean } \\
\text { Square }\end{array}$ & $\mathrm{F}$ & Sig. \\
\hline \multirow{5}{*}{\multicolumn{2}{|c|}{$\begin{array}{l}\text { ACHIEVEMEN Betwee } \\
\text { T } *_{n} \\
\text { MOTIVATION Groups }\end{array}$}} & (Combinec & 1968.808 & 36 & 26.911 & 5.444 & .00 \\
\hline & & ) & & & & & 0 \\
\hline & & Linearity & 617.619 & 1 & 617.61 & 124.94 & .00 \\
\hline & & & & & 9 & 6 & 0 \\
\hline & & $\begin{array}{l}\text { Deviation } \\
\text { from } \\
\text { Linearity }\end{array}$ & 351.189 & 35 & 10.034 & 2.030 & $\begin{array}{l}.00 \\
5\end{array}$ \\
\hline & \multicolumn{2}{|c|}{ Within Groups } & 365.788 & 74 & 4.943 & & \\
\hline & \multirow{2}{*}{\multicolumn{2}{|c|}{ Total }} & 1334.59 & 11 & & & \\
\hline & & & & 0 & & & \\
\hline
\end{tabular}

The linearity testing from students' motivation and English achievement, that the value F-obtained of the $\mathrm{F}$ deviation is 5.444. The value significant of linearity is 
0.000. Because the significant is lower than 0.05 or $0.000<0.05$, so between learning motivation and English achievement is linier.

Since the computation of linearity testing shows that the data are linear, the researcher continued to test the hypothesis. As for the Hypothesis this research is developed as follows:

There is significant correlation between students' motivation and English achievement at secondary school level.

To test hypothesis, the researcher used SPSS 25 for windows to analyze the data. Further, the explanations on correlation of instruments are presented as follows:

\begin{tabular}{llll|l}
\hline Correlations & \multicolumn{3}{c}{ MOTIVATION } & ACHIEVEMENT \\
\hline MOTIVATION & $\begin{array}{l}\text { Pearson } \\
\text { Correlation }\end{array}$ & 1 & $.680^{* *}$ \\
& $\begin{array}{lll}\text { Sig. (2-tailed) } \\
\text { N }\end{array}$ & 111 & .000 \\
\hline ACHIEVEMENT Pearson & $.680^{* *}$ & 111 \\
& \begin{tabular}{lll} 
Correlation \\
\cline { 2 - 4 }
\end{tabular} & Sig. (2-tailed) & .000 & 11 \\
\cline { 2 - 4 } & $\mathrm{N}$ & 111 & 111 \\
\hline
\end{tabular}

**. Correlation is significant at the 0.01 level (2-tailed).

Based on the table above, it shows that the coefficient of correlation (r) between students' motivation and English achievement is 0.680 with significantly $(p)=0.000$. It means that there is significant correlation between students' motivation and English achievement because the level of significance that was $0.000<0.05$.

Furthermore, the researcher showed the pattern of relationship between learning motivation and English learning achievement by using scatterplot as follows:

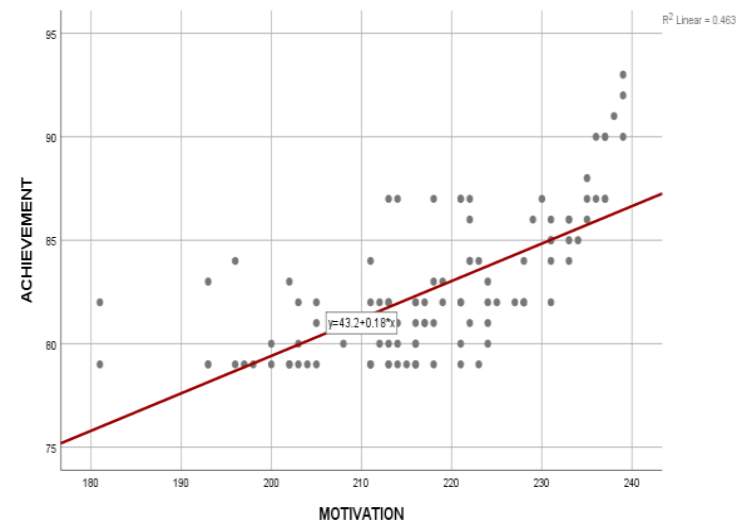

Based on the scatterplot above, it shows that there is significant correlation between students' motivation and English achievement. Also, from the graph above it can be seen that the distribution of points of the data pair is getting closer to the straight line which shows that there is significant correlation between two variables; students' motivation and English achievement that are getting stronger. In this case, the more motivation students have in studying, the higher achievement score will be. Furthermore, referring to the result of testing hypothesis, the researcher concluded that there is significant correlation between students' motivation and English achievement. It is based the result of Pearson Product - Moment Correlation; 0.680. Therefore, by seeing the result of Pearson Product - Moment Correlation, it can be concluded that the level of correlation between students' motivation and English achievement is strong relationship.

Furthermore, from the explanation above, it also can be known that the coefficient determination between learning motivation and English learning achievement is 0.680 . So, the contribution of learning motivation to English learning achievement is that $\mathrm{CD}=\mathrm{r}^{2} \times 100 \%=$ $(0.680)^{2} \times 100 \%=46 \%$. It means that $46 \%$ variance of English learning achievement is influenced by the learning motivation. While $54 \%$ is influenced by other factors, one of them is the use of technology in teaching and learning process as Suriaman (2015) states:

"In the era of globalized technological advances that have affected all aspects of human life, such in the fields of economics, politics, culture, art and even in the field of education, so that aspects of education must carry out positive innovations for the advancement of education at the university and school level, not only the innovation in the field of curriculum, infrastructure and facilities, but also comprehensive innovation by using information technology in teaching and learning activities."

It means that the use of technology has the important role in improving the quality of learning and making learning more interesting. Also, the most important thing is to increase the learning motivation of the students through the appearance of attractive and interactive media generated by the use of technology.

\section{CONCLUSION}

The purpose of this research is to know whether there is significant correlation between two variables; students' motivation and English achievement. Therefore, based on the result of this research, it can be concluded that there is strong relationship between students' motivation and English achievement at secondary school level since the value of coefficient correlation (r) is 0.680 , in which the level of significance that was $0.000<0.05$. Therefore, it can be stated that the more motivation students have in studying, the higher achievement score will be.

\section{AUTHORS' CONTRIBUTIONS}

Rosmawati Mastur is as the first author, Rofiqoh Rofiqoh is as the second author, and Aminah Suriaman is as the third author. They conceived the presented idea of this research. The first author designed the research by applying the correlational study in a quantitative 
design. Then, she collected the data through questionnaire developed by Gardner; Attitude / Motivation Test Battery: International AMTB Research Project (English version) and the result of students' average scores coming from the first semester of the seventh grade up to the sixth semester of the ninth grade. In order to analyze the data, the first author applied Pearson Product - Moment Correlation which was computed by the Statistical Package for Social Science (SPSS) 25 for windows. After that, in writing this manuscript the first author was assisted by the second author and the third author.

\section{ACKNOWLEDGMENTS}

Great gratitude to Dr. Hj. Rofiqoh, M.Ed, as the supervisor and Dr. Hj. Aminah, S.Pd, M.Pd, M.Ed, as her co-supervisor for their patience, guidance, valuable ideas, corrections, insightful comments, suggestions, and support during the consultation in helping to conduct this research. It would not have been finished without their sincere patient and encouraged guidance.

\section{REFERENCES}

[1] Adams, A. 1996. Even Basic Needs of Young Are Not Met. Retrieved from http://tc.education. pitt.edu/library/SelfEsteem

[2] Arifin, Z. 2012. Penelitian Pendidikan Metode Penelitian dan Paradigma Baru. PT. Bandung. Remaja Sodakarya.

[3] Azwar, S. 2012. Penyusunan Skala Psikologi edisi 2. Yogyakarta. Pustaka Pelajar.

[4] Bhat, M. A. 2013. Research Article Academic Achievement of Secondary School Students in Relation To Self-Concept. International Journal of Recent Scientific Research, 4, 738-741.

[5] Brown, H, D. 2004. Language assessment piciples and classroom paractice. http://pbi.mercubuanayogya.ac.id/wp-content/uploads/2014/09/EbookBrown-LanguageAssessment.pdf

[6] Chandra Ritu, and Azimuddin, S. 2013. Influence of Socio Economic Status On Academic Achievement Of Secondary School Students Of Lucknow City. International Journal of Scientific \& Engineering Research, 4(12), 1952-1960. http://www.ijser.org

[7] Fraenkel, J, R. 2012. How to Design and Evaluate Research in Education 8th ed. New York: The McGrew - Hill.

[8] Gage, N. L and David C. B. 1984. Educational Psychology. Boston: Houngton Mifflin Company.
[9] Gardner, R. C. 2004. Attitude / Motivation Test Battery: International AMTB Research Project. The University of Western Ontario, http://publish.uwo.ca/ gardner/docs/englishamtb.p d.

[10] Gbollie, C., and Keamu, H. P. 2017. Student Academic Performance: The Role of Motivation, Strategies, and Perceived Factors Hindering Liberian Junior and Senior High School Students Learning. Education Research International, 2017, 1-11. https://doi.org/10.1155/2017/1789084

[11] Gilakjani, A. P., Leong, L.-M., and Sabouri, N. B. 2012. A Study on the Role of Motivation in Foreign Language Learning and Teaching. International Journal of Modern Education and Computer Science, 4(7), 9-16. https://doi.org/10.5815/ijmecs.2012.07.02

[12] Harmer, J. 2001. The Practice of English Language Teaching 3rd ed. Cambridge: Longman.

[13] Hornby, A.S. 2003. Oxford Advanced Learner's Dictionary of Current English. Oxford. University Press.

[14] Kementrian Pendidikan dan Kebudayaan. 2018. Buku Guru Bahasa Inggris Think Globally Act Locally Kelas IX. Pusat Kurikulum dan Perbukuan, Balitbang, Kemendikbud.

[15] Kpolovie, P., Joe, A., and Okoto, T. 2014. Academic Achievement Prediction: Role of Interest in Learning and Attitude towards School. International Journal of Humanities Social Sciences and Education, 1(11), 73-100. www.arcjournals.org

[16] Kitjaroonchai, N. 2013. Motivation Toward English Language Learning of Students in Secondary and High Schools in Education Service Area Office 4, Saraburi Province, Thailand. International Journal of Language and Linguistics, $1(1)$,

https://doi.org/10.11648/j.ijll.20130101.14

[17] Krashen, S. 2005. The hard work hypothesis: Is doing your homework enough to overcome the effects of poverty? Multicultural Education, 12(4), 16-19.

[18] Kurt, P. Y., and Kecik, I. 2017. The effect of ARCS motivational model on student motivation to learn English. European Journal of Foreign Language Teaching, 2(1), 22-44. doi:10.4304/jltr.2.1.68-72.

[19] Majoribanks. 1996. Family Learning Environments and Students' Outcomes: A Review. Journal of 
Comparative Family Studies vol 27 no.2 ,pp. 373394.

[20] Ningrum, S., and Matondang, S. A. 2017. The correlation between students' motivation and achievement in reading comprehension. The International Journal of Social Sciences and Humanities Invention, 5(7). https://doi.org/10.18535/ijsshi/v4i7.10

[21] Nunan, D. 1992. Research Method in Language Learning. Cambridge: Cambridge University Press.

[22] Ryan, R. M., and Deci, E. L. 2000. Intrinsic and Extrinsic Motivations: Classic Definitions and New Directions. Contemporary Educational Psychology, 25(1), 54-67. https://doi.org/10.1006/ceps.1999.1020

[23] Salkind, N,J. 2017. Statistics for People Who (Think They) Hate Statistics. London. SAGE Publications, Inc.

[24] Santrock, J, W. 2008. Educational Psycology. New York: Mc-Grew Hill

[25] Scholarship, T. 2011. 2011 Applied Science and Technology Scholarship Why is Academic Success Important? By Janelle Regier.
[26] Sharma, D., and Sharma, S. 2018. Relationship between Motivation and Academic Achievement. International Journal of Advances in Scientific Research, 4(1), 01 https://doi.org/10.7439/ijasr.v4i1.4584

[27] Suriaman, A. 2015. Strategies in Promoting Independent Learning through Self-Access Center at Tadulako University. Asian EFL JournalProfessional Teaching Article, 88.

[28] Ur, P. 1996. A Course in English Teaching. Washington DC. American Psychological Association.

[29] US Department of Education. 2003. Confidence: Helping your child through early adolescence. Retrieved from http://www.ed.gov/parents/academic/help/adolesce nce/part 8.html

[30] Zhang, J. 2015. Improving English listening proficiency: The application of ARCS learningmotivational model. English Language Teaching, 8(10), 1-6. doi:10.5539/elt.v8n10p1. 